\title{
PEMBELAJARAN BAHASA INGGRIS BAGI ANAK USIA DINI VERSUS BUDAYA LOKAL
}

\author{
Charlotte A.H. ${ }^{1}$
}

\begin{abstract}
ABSTRAK
Mengenalkan bahasa Inggris sejak dini seyogyanya perlu didukung oleh sarana dan prasarana yang memadai. Guru sebagai komponen pengelola proses pembelajaran perlu memahami kerangka berpikir anak usia dini (AUD) agar pengelolaan pembelajaran dapat dilakukan dengan baik. Pembelajaran hendaknya dikelola sedemikian rupa agar tercipta kegiatan belajar yang bermakna dan menyenangkan. Penggunaan nyanyian (song) sebagai media pembelajaran merupakan salah satu upaya bagi terciptanya pembelajaran bahasa Inggris yang bermakna dan menyenangkan, yang "asyik", bagi anak usia dini. Pembelajaran bahasa Inggris dapat disiasati dengan berbagai cara - metode dan teknik serta permainan (games) maupun media pembelajaran - yang akan membuat anak tidak merasa sedang belajar tetapi sedang bermain, sehingga anak merasa asyik belajar Inggris. Bahkan budaya lokal pun dapat digunakan sebagai sarana ampuh dalam menciptakan pembelajaran yang asyik bagi AUD. Tulisan ini akan membahas pembelajaran bahasa Inggris bagi AUD secara umum, dan belajar melalui nyanyian secara khusus. Pembelajaran bahasa Inggris yang menyenangkan akan menghindari AUD dari kejenuhan dan rasa bosan atau bahkan trauma terhadap bahasa Inggris.

Kata kunci: pembelajaran; bahasa Inggris; nyanyian; anak usia dini.
\end{abstract}

\section{A. PENDAHULUAN}

Mengenalkan bahasa Inggris sejak dini bagi anak Indonesia dapat diasumsikan sebagai dukungan terhadap pernyataan Menteri Pendidikan dan Kebudayaan Republik Indonesia pada peringatan hari Pendidikan Nasional tanggal 2 Mei 2013. Mendikbud RI, Mohammad Nuh, mencanangkan generasi emas sebagai tema peringatan Hardiknas tahun 2013. Pencanangan tersebut didasari pada kenyataan bahwa sejak 2010 sampai 2035 Indonesia mendapatkan bonus demografi, yakni populasi usia produktif paling besar sepanjang sejarah berdirinya negara ini.

Investasi besar-besaran dalam bidang pengembangan sumber daya manusia akan dilakukan sebagai upaya menyambut 100 tahun Indonesia merdeka, pada 2045 mendatang. Mendikbud juga mendukung gerakan Paudnisasi, untuk mendorong perluasan akses pendidikan di semua jenjang sebagai upaya membangkitkan generasi emas. Kualitas pendidikan yang baik dan merata merupakan kunci sukses membangkitkan generasi emas (http://edukasi.kompas.com/read/2012/05/02/ 11324267/Kemdikbud.Ingin.Cetak.Generasi.Emas tersedia: Rabu 2 Mei 2013).

Pencanangan generasi emas perlu ditindaklanjuti dengan mengenalkan bahasa Inggris sejak dini, karena bahasa Inggris merupakan bahasa internasional. Penguasaan bahasa Inggris merupakan kendaraan untuk berkiprah secara global dan

\footnotetext{
${ }^{1}$ Dosen UPI Kampus Cibiru
} 
mendunia. Dengan mengenalkan bahasa Inggris sedini mungkin, berarti membekali para insan bangsa untuk dapat mengarungi dunia ilmu pengetahuan dan teknologi secara leluasa, namun tetap mengutamakan budaya nasional.

Pembelajaran bahasa Inggris bagi anak di tingkat PAUD sejalan dengan pendapat para ahli, yang mengatakan bahwa sebenarnya kemampuan anak usia dini lebih cemerlang dari pada apa yang dibayangkan oleh orang dewasa! Mereka dapat melakukan penjumlahan sebelum mereka mampu berhitung. Mereka dapat mengerti seratus kata sebelum mereka mampu berbicara dengan lancar. Dan pada usia tiga bulan daya ingat mereka sangat tinggi, lebih tinggi dari apa yang dibayangkan oleh orang dewasa (Cole \& Cole, 2001). Pandangan ini menepis asumsi bahwa upaya mengenalkan bahasa asing kepada anak usia dini akan mengganggu perkembangan bahasanya.

Tulisan ini mencoba memberikan gambaran tentang alasan perlunya mengenalkan bahasa Inggris sejak dini dan upaya yang dapat dilakukan. Pembahasan meliputi tiga hal, yakni kerangka teori tentang perkembangan anak usia dini (AUD); perkembangan bahasa anak usia dini; serta upaya mengenalkan bahasa Inggris kepada anak sejak dini berbasis budaya lokal.

\section{B. PEMBAHASAN}

\section{Teori Perkembangan AUD dan Perkembangan Bahasa AUD}

Mengenal anak usia dini adalah mempelajari perkembangan fisik, kognitif, kejiwaan, dan perkembangan sosial mereka yang akan terus berkembang sejalan pertambahan usia (Cole \& Cole, 2001). Dengan mengenal anak usia dini serta berbagai aspek yang mempengaruhi perkembangannya, akan mempermudah upaya menyelami siapakah anak usia dini dan bagaimana cara memperlakukan mereka. Pemahaman tentang anak usia dini akan menjadi pedoman bagi guru dalam mengajar mereka, termasuk pula dalam mengajarkan bahasa asing, dalam hal ini bahasa Inggris. Itulah sebabnya teori tentang anak usia dini diperlukan sebelum sampai pada teori tentang pengajaran bahasa Inggris bagi anak usia dini.

Beberapa ahli antara lain John Dewey, Maria Montessori, Erik Erikson, Jean Piaget, dan Lev Vigotsky mengetengahkan tentang berbagai terkait teori tentang anak usia dini. Menurut John Dewey anak usia dini memerlukan sarana belajar yang aktif dan interaktif, yang berpusat pada anak. Sedangkan Maria Montessori menyatakan bahwa anak usia dini hendaknya disaranai dengan lingkungan yang penuh keindahan, keteraturan, dan kenyamanan, serta sesuai pancaindera anak (Mooney, 2000).

Erikson (Mooney, 2000: 40) mengemukakan bahwa anak usia dini sangat kritis dalam hal perkembangan kepercayaan (trust), otonomi (autonomy) atau kemandirian, dan inisitiatif. Seorang anak yang memiliki kepercayaan tinggi pada dirinya sendiri maupun lingkungannya akan mudah beradaptasi dengan lingkungannya. Kepercayaan ini tercipta ketika seorang anak yang baru lahir merasakan kenyamanan di sekelilingnya baik secara fisik, mental, maupun spiritual. Kondisi ini diperlukan bagi anak dalam mempelajari bahasa Inggris.

Jean Piaget membagi perkembangan anak ke dalam beberapa tahap. Anak usia dini berada pada tahap praoperasional. Pada tahap ini anak dapat menilai 
sesuatu berdasarkan kenyataan yang ditampilkan melalui simbol-simbol termasuk gambar, kata-kata, dan isyarat. Dengan demikian anak dapat memikirkan sesuatu tentang benda atau obyek maupun peristiwa tanpa menghadirkan obyek tersebut di hadapan anak. Namun pada tahap ini anak masih sering bingung tentang hubungan sebab akibat (Cole \& Cole, 2001: 344). Lebih lanjut Piaget mengemukakan bahwa anak usia dini lebih mampu mengumpulkan informasi melalui apa yang mereka alami sendiri, dari pada jika diberitahukan kepadanya (Mooney, 2000: 69).

Vygotsky menekankan proses penguasaan bahasa pada anak melalui dialog atau percakapan. Melalui percakapan atau dialog, orang dewasa mentransfer pengetahuan yang terdapat dalam budaya kepada anak. Selama proses pembelajaran berlangsung, bahasa yang digunakan oleh anak menjadi sarana transforamasi intelektual. Dengan cara mengulang, atau menirukan ujaran yang digunakan orang tua, anak belajar bahasa sekaligus budaya orang tuanya. Proses inilah yang dimaksud oleh Vygotsky sebagai tema perkembangan dalam proses internalisasi (Mooney, 2000).

Berbagai pendapat yang dikemukakan oleh para ahli di atas merupakan pemaparan tentang perkembangan anak usia dini. Pengenalan kemampuan berpikir anak usia dini akan memberikan pemahaman terhadap upaya mengenalkan bahasa Inggris kepada anak usia dini.

Cameron (2001) mengemukakan bahwa anak usia dini memiliki kelebihan yang unik, yang berbeda dari pembelajar di tingkat yang lebih tinggi, atau orang dewasa. Keunikan dan kelebihan yang terdapat pada anak usia dini adalah potensi besar yang dimiliki anak untuk belajar, melebihi apa yang dapat dibayangkan atau dipahami oleh orang dewasa.

Perkembangan bahasa mengenal empat teori utama, yakni teori behavioristik yang dikemukakan oleh B.F. Skinner, teori nativistik yang dikemukakan oleh Noam Chomsky, teori empirik yang bertentangan dengan teori nativistik, serta teori interaksi. Keempat teori ini akan dibahas secara terpisah pada paragraph selanjutnya.

Teori behavioristik yang dikemukakan oleh B. F. Skinner menyatakan bahwa bahasa dipelajari melalui pengkondisian dengan memberikan penguatan dan peniruan (Cameron, 2001). Penguatan terjadi karena adanya proses pengulangan terhadap stimulus yang diberikan. Penekanan pada teori ini adalah bahwa setiap anak ketika dilahirkan tidak memiliki kemampuan bawaan untuk menguasai atau memahami suatu struktur linguistik tertentu.

Anak lahir ke dunia ini seperti layaknya selembar kain putih bersih, dan lingkungannyalah yang kelak akan membentuk semua kemahiran perilakunya termasuk kemahiran perilaku lingualnya. Pembentukan kemahiran ini terjadi melalui pengalaman dan proses belajar.

Noam Chomsky mengemukakan teori nativistik dalam perkembangan bahasa. Teori ini menyatakan bahwa semua anak sejak dilahirkan telah memiliki kemampuan berbahasa yang dikenal dengan sebutan LAD (Language Acquistion Device), yakni potensi diri untuk memperoleh bahasa yang memampukan anak memproduksi sebuah kalimat yang terdiri dari kata-kata yang telah dikenalnya. Pernyataan ini didasari oleh pandangan yang menyatakan apa yang didengar oleh 
anak - masukan linguistik - cukup memadai untuk memberi penjelasan kepada mereka sampai pada tahap belajar bahasa (Cameron, 2001).

Berbeda dengan teori behavioristik, yang menyatakan bahwa kemahiran berbahasa anak dibentuk oleh pengaruh lingkungannya, teori ini berasumsi bahwa bahasa merupakan pemberian biologis. Bahasa terlalu kompleks dan mustahil untuk dapat dipelajari dalam waktu yang relative singkat. Maka beberapa aspek penting yang menyangkut sistem bahasa tentu sudah ada dalam diri setiap anak saat dilahirkan.

Teori empirik bertentangan dengan apa yang dikemukakan oleh Chomsky. Teori ini mengemukakan bahwa masukan linguistik yang diterima anak tidak cukup memadai sehingga tidak dapat dikatakan bahwa anak memiliki LAD dalam pemerolehan bahasa. Karakteristik teori ini tampak pada konstruksi model bahasa yang dipelajari dan aspek linguistik yang diproduksi oleh anak. Teori empirik sangat dipengaruhi oleh teori belajar statistikal (Wikipedia).

Dalam filsafat, empirisme adalah teori pengetahuan yang menyatakan bahwa pengetahuan timbul dari pengalaman. Empirisme adalah salah satu dari sekian banyak pandangan yang memusatkan perhatian pada pengetahuan manusia, yang dikenal dengan epistemology. Empirisme menekankan peran pengalaman dan pembuktian, terutama persepsi sensori dalam membentuk gagasan (Wikipedia).

Teori yang keempat adalah teori perspektif, yang terdiri dari dua komponen. Teori perspektif adalah perpaduan dua teori terdahulu, yaitu teori nativisme dan teori behaviorisme. Teori ini terdiri dari dua komponen, yaitu proses informasi yang diuji melalui statistik sebagai komponen pertama. Data statistic ini akan menunjukkan bahwa otak memiliki kemampuan yang sangat tinggi dalam mendeteksi berbagai pola. Komponen kedua adalah interaksi sosial yang menekankan adanya keinginan yang kuat dalam diri seseorang untuk mengerti orang lain dan untuk dimengerti oleh orang lain.

Interaksionisme adalah mikro-sosiologi yang berkeyakinan bahawa makna dihasilkan melalui interaksi secara individual. Interaksi social melalui proses tatap muka teridiri dari tindakan, reaksi, dan adaptasi mutual antara dua individu atau lebih.

Interaksi berlaku bagi semua bahasa, termasuk bahasa tubuh dan sikap. Tujuan interaksi social adalah untuk berkomunikasi dengan orang lain. Jika interaksi yang sedang berlangsung terancam berakhir sebelum salah satu dari individu yang terlibat menghendakinya, interaksi dapat terus berlangsung dengan mengabaikan hal yang mengganggu atau masalah yang timbul. Erving Goffman (1992) menggarisbawahi pentingnya kontrol dalam interaksi. Seseorang harus mencoba mengontrol sikap orang lain selama interaksi berlangsung untuk dapat menyerap informasi yang diperlukan dan untuk mengontrol imajinasi persepsinya sendiri. Konsep penting yang termasuk dalam teori interaksi adalah 'peran sosial', dan pandangan 'presentasi diri' yang dikemukakan oleh Goffman.

\section{Mengenalkan Bahasa Ingris Sejak Dini}

Penelitian di bidang pemerolehan bahasa (Postovsky 1974; Winitz 1981; Krashen \& Terrell 1983) mengungkap bahwa pembelajaran bahasa asing 
diasumsikan serupa dengan pemerolehan bahasa pertama. Karakteristik pendekatan Comprehension-Based memperlihatkan perbedaan maupun persamaan pendekatan ini dengan pendekatan lainnya dalam pengajaran bahasa Inggris. Dalam pendekatan ini kemampuan menyimak sangat diutamakan, dan dianggap sebagai kemampuan dasar bagi kemampuan berbahasa lainnya, yaitu berbicara, membaca, dan menulis (Celce-Murcia 2000:8). Dengan demikian pendekatan ini dapat digunakan untuk mengenalkan bahasa Inggris kepada anak usia dini.

Selain pendekatan Comprehension-Based, pendekatan komunikatif juga sangat disarankan dalam pengajaran bahasa Inggris di Indonesia, agar anak mampu menggunakan bahasa Inggris sebagai alat komunikasi. Tujuan utama pengajaran bahasa adalah kemampuan untuk berkomunikasi dalam bahasa yang dipelajari. Pengajaran bahasa perlu melibatkan unsur semantik dan fungsi sosial bahasa, bukan hanya struktur linguistik.

Bermain peran dalam drama atau dialog tertentu akan membiasakan anak menggunakan bahasa target dalam konteks yang berbbeda-beda. Kegiatan dan materi belajar hendaknya sesuai dengan kenyataan, bukan rekayasa, untuk merefleksikan situasi dan tuntutan kehidupan. Guru berperan sebagai fasilitator komunikasi dan sewaktu-waktu mengoreksi kesalahan. Guru selayaknya mampu menggunakan bahasa target dengan baik.

Pendekatan komunikatif sesuai dengan namanya, mendasari pengajaran bahasa yang menekankan pada penggunaan bahasa secara lisan maupun tulisan untuk berkomunikasi. Namun pendekatan ini lebih menekankan pada bentuk latihan bermakna, bukan rekayasa, dan tidak seperti latihan-latihan yang hanya berupa pengulangan.

Selain pendekatan Comprehension-Based dan pendekatan Komunikatif, pendekatan yang lebih sesuai lagi bagi pembelajaran bahasa Inggris bagi anak usia dini adalah pendekatan Total Physical Response (TPR) yang dikembangkan oleh James Asher pada tahun 1977. Pendekatan ini melibatkan kegiatan anak secara fifik sebagai tanggapan terhadap instruksi ataupun sesuatu yang sedang dipelajarinya.

Dalam mengenalkan bahasa Inggris kepada anak melalui pembelajaran bahasa Inggris bagi anak usia dini, penerapan songs, chants and rhymes (lagu dan nyanyian) dapat digunakan. Istilah song sering diartikan sebagai lagu atau nyanyian. Sedangkan chant dapat diterjemahkan yel-yel yang dapat menambah semangat. Rhyme dapat berarti nyanyian dengan rima tertentu, biasanya memiliki bunyi akhir yang sama pada beberapa ataupun setiap barisnya. Chant dan rhyme dapat dibentuk dari puisi.

Lagu dan nyanyian adalah kegiatan yang sangat bermanfaat dan efektif untuk pembelajaran bahasa bagi anak usia dini. Pada pembelajaran bahasa, kegiatan ini sangat bermanfaat terutama bagi anak yang belum mampu memproduksi bahasa. Kegiatan bernyanyi dapat meningkatkan perkembangan bahasa dan perkembangan fisik motorik, terutama jika kegiatan tersebut terintegrasi dengan musik dan gerakan (dance). Kegiatan bernyanyi dapat memfasilitasi anak dengan gaya belajar yang berbeda; seperti visual, auditory dan kinaesthetic (Linse, 2005). 
Menyanyi bukanlah sesuatu yang sulit dipelajari maupun dilakukan, bahkan keseharian anak tidak terlepas dari kegiatan menyanyi. Demikian pula yang terjadi di lingkungan pendidikan bagi AUD.

Kegiatan bernyanyi dalam bahsa Inggris dapat dilakukan untuk meningkatkan kemampuan menyimak (listening). Hal ini sesuai dengan anjuran bahwa keterampilan yang perlu diutamakan dalam pengajaran bahasa Inggris untuk anak usia dini adalah oral skills. Keterampilan yang termasuk oral skills adalah keterampilan menyimak (listening) dan keterampilan berbicara (speaking).

Kegiatan bernyanyi dapat dikombinasikan dengan penerapan pendekatan TPR (Total Physical Response). Pada pelaksanaannya, TPR memberi kesempatan luas bagi anak untuk merespon instruksi atau perintah guru dalam bahasa Inggris dengan gerakan-gerakan fisik.

Pada kegiatan ini, anak tidak dituntut untuk merespon secara verbal. Dengan demikian, kegiatan ini dapat dilakukan ketika anak usia dini masih berada dalam tahapan silent period (periode diam). Pada periode ini, anak sedang belajar secara aktif melalui indera pendengarannya dengan menyerap bahasa yang didengarnya sebanyak mungkin. Akan tetapi, walaupun telah memiliki cukup banyak kosa kata, anak belum siap untuk memproduksi bahasa baik secara lisan maupun tulisan.

Anak-anak sangat menyukai song, rhyme dan chant (Brewster, Ellis, \& Girard, 2002). Terlebih lagi nyanyian dan lagu mempunyai sifat pengulangan dan irama yang sesuai digunakan sebagai kendaraan dalam pembelajaran bahasa. Manfaat inilah yang membuat banyak program pengenalan bahasa, terutama bagi anak usia dini yang menerapkan kegiatan bernyanyi.

Manfaat dan potensi song, chant and rhyme dalam pembelajaran bahasa Inggris untuk anak usia dini, yaitu memberikan kesempatan bagi anak untuk belajar sambil bermain dan menjalani proses belajar yang menyenangkan. Dengan memilih jenisjenis song, chant and rhyme yang sesuai bagi anak, menjadikan pembelajaran bahasa Inggris bagi anak usia dini lebih bermakna dan menyenangkan.

Bernyanyi sangat bermanfaat untuk melatih kemampuan anak dalam mengucapkan kata bahasa Inggris. Dalam bahasa Inggris terdapat penekanan (stress), irama dan intonasi yang berbeda dari bahasa Indonesia. Dengan menyajikan kegiatan bernyanyi, anak-anak dapat mempelajarinya dalam situasi yang lebih menyenangkan dan bermakna.

Banyak lagu yang dapat digunakan dalam pembelajaran bahasa Inggris untuk anak usia dini. Lagu yang disertai gerakan dapat membuat anak-anak belajar kosakata baru tanpa harus diterjemahkan ke dalam bahasa Indonesia. Salah satu contoh seperti lagu yang berbentuk action songs adalah lagu If You're Happy and You Know It.

Berikut ini syair lagu If You're Happy and You Know It: 
Menyanyikan lagu
If you're happy and you know it clap your hand

If you're happy and you know it clap your hand

If you're happy and you know it and you really want to show it

If you're happy and you know it clap your hand

If you're happy and you know it stomp your feet

If you're happy and you know it stomp your feet

If you're happy and you know and you really want to show it

If you're happy and you know it stomp your feet

If you're happy and you know it shout hooray

If you're happy and you know it shout hooray

If you're happy and you know it and you really want to show it

if you happy and you know it shout hooray
Gerakan

(bertepuk tangan)

(bertepuk tangan)

(bertepuk tangan)

(menghentakkan kaki ke lantai)

(menghentakkan kaki ke lantai)

(menghentakkan kaki ke lantai)

(berteriak hore)

(berteriak hore)

(berteriak hore)

Demikian pula dengan chant, yang dapat juga diucapkan serta melakukan gerakan-gerakan pada saat yang sama. Gerakan ini dimaksudkan untuk memperjelas makna kata dalam bahasa Inggris sehingga tidak perlu diterjemahkan ke dalam bahasa Indonesia. Berikut ini salah satu contoh chant yang berjudul Five Little Monkeys:

\begin{tabular}{|l|l|}
\hline \multicolumn{1}{|c|}{ Mengucapkan chant } & \multicolumn{1}{c|}{ Gerakan } \\
\hline Five little monkeys jumping on the bed & (melakukan gerakan lompat) \\
One fell off and bumped his head & (menyentuh kepala dengan telapak tangan) \\
Mummy phoned the doctor and the doctor said & $\begin{array}{l}\text { (melakukan gerakan menelepon) } \\
\text { (mengacungkan telunjuk sambil } \\
\text { "No more monkey jumping on the bed!" }\end{array}$ \\
&
\end{tabular}

Chant di atas dilanjutkan dengan:

Four little monkeys

Three little monkeys

Two little monkeys

One little monkey

Bentuk lain dari nyanyian yang dapat digunakan dalam pembelajaran bahasa Inggris bagi anak usia dini adalah rhyme, yaitu nyanyian yang mempunyai bunyi kata yang sama di akhir baris. Rhyme disebut juga puisi anak. Melalui rhyme, pembelajaran bahasa Inggris untuk anak usia dini dapat dilakukan dengan lebih menyenangkan. Berikut adalah contoh rhymes yang dapat disajikan dalam pembelajaran bahasa Inggris, dengan udul Baa Baa Black Sheep: 
Baa baa black sheep, have you any wool?

Yes sir, yes sir, three bags full

One for the master, one for the dame,

And one for the little boy

Who live down the land

Ketiga kegiatan pembelajarn tersebut mendukung pernyataan bahwa anak lebih senang pada KBM (Kegiatan Belajaran Mengajar) yang melibatkan fisik. Pembelajaran yang bermakna dan yang menyenangkan tidak terlepas dari lingkungan anak termasuk budaya lokal yang mewadahi pertumbuhan anak.

\section{Mengenalkan Bahasa Ingris Berbasis Budaya Lokal}

Bangsa Indonesia memiliki sangat banyak kekayaan dan keragaman, baik dari segi bahasa maupun dialek, tradisi dan kebiasaan, bahkan budaya. Kekayaan ini ditunjang oleh kondisi geografis yakni negeri yang terdiri dari ribuan pulau. Kekayaan alam yang berpengaruh terhada kekayaan budaya ini perlu ditanamkan pada anak sejak dini. Itulah sebabnya pengajaran bahasa Inggris sejak dini perlu didukung oleh sarana yang ada, yaitu budaya lokal.

Majid, Abd. (2014) mengemukakan bahwa kekayaan dan keragaman budaya lokal, akan terisolasi dengan sendirinya manakala kita tidak sejak dini menanamkan tekad kuat bahu membahu untuk memperkuat dan melestarikan budaya lokal kita yang kaya akan nilainilai luhur.

Pengenalan bahasa Inggris kepada AUD seyogyanya tidak terpisahkan dari pengenalan budaya lokal. Sebaliknya budaya lokal dapat dijadikan sarana, media, bahkan materi pembelajaran bahasa Inggris. Sebagai contoh, anak dapat dilatih mengenalkan budaya, kebiasaan, atau tradisi di rumah atau di desanya dengan berbahasa Inggris. Pengenalan nama buah-buahan yang ada di Indonesia, berbagai permainan tradisional, beragam busana daerah dapat dikenalkan kepada anak dalam pembelajaran kosakata bahasa Inggris. Dengan kata lain, menambahkan pemahaman anak tentang budaya lokal melalui pembelajaran bahasa Inggris.

Pendekatan yang sesuai bagi bentuk pembelajaran ini adalah pendekatan etnopedagogi dan pendekatan interkultural. Hal ini sejalan dengan apa yang dikemukakan oleh Grabe (2002) bahwa pembelajaran bahasa kedua, dalam hal ini bahasa Inggris, perlu melibatkan pemahaman anak tentang budaya lokal dan lingkungan anak sendiri (Richards \& Renandya, 2002: 280). Sedangkan Santoso (2013) mengemukakan bahwa melalui etnopedagogi kita akan untuk selalu 'menoleh' pada kearifan lokal yang dimiliki bangsa Indonesia, sehingga kekhawatiran akan tercerabutnya jati diri sebagai bangsa Indonesia bisa dieliminir (http: L/www.academia.edu/5180839/Pembelajaran_Bahasa_Asing_di_Indonesia_antara_ Globalisasi_dan_Hegemoni). Etnopedagogi dalam pembelajaran bahasa Inggris bagi AUD akan memacu anak untuk mengenalkan budaya dan tradisi leluhurnya kepada penutur asli bahasa Inggris.

Selain pendekatan etnopedagogi, pendekatan interkultural pun dapat digunakan dalam pembelajaran bahasa Inggris bagi AUD. Santoso (2013) mengemukakan bahwa pendekatan interkultural bertujuan untuk mengembangkan 
kompetensi komunikatif dan interkultural pada diri pembelajar. Kompetensi interkultural merupakan kemampuan berempati terhadap budaya asing dengan berlandaskan pada budaya sendiri.

Melalui pendekatan ini AUD dapat mengenal dua budaya sekaligus, yaitu budaya lokal dan budaya asing yang dipelajari melalui bahasa Inggris. Berbagai sarana dapat digunakan, seperti alat musik tradisional yang merupakan kekayaan budaya Indonesia dapat dikenalkan kepada AUD melalu pembelajaran bahasa Inggris.

\section{PENUTUP}

Mengenalkan bahasa Inggris kepada anak usia dini oerlu disiapkan dengan adanya guru-guru yang memahami teori tentang kerangka perkembangan anak usia dini dan juga perkembangan bahasanya. John Dewey, Maria Montessori, Erik Rikson, dan Lev Vygotsky adalah para ahli di bidang perkembangan kognitif anak. Para ahli ini mengemukakan bahwa anak usia dini dapat belajar dengan baik jika diberikan sarana yang memadai dan sarana bermain yang berpendidikan (edukatif).

Pemahaman tentang kerangka berpikir anak dapat mendorong guru untuk menggunakan songs, rhymes, dan chants sebagai sarana pembelajaran yang menyenangkan dan bermakna. Pendekatan dan media yang direkomendasikan untuk pembelajaran bahasa Inggris bagi anak usia dini adalah pendekatan comprehension- based, communicative approach, dan bernyanyi.

Kemampuan anak dalam belajar bahasa Inggris dapat dimanfaatkan sebagai sarana untuk menambah pengenalan dan pemahaman budaya lokal. Pendekatan etnopedagogi dan pendekatan interkultural sesuai untuk digunakan dalam pembelajaran bahasa Inggris bagi AUD.

\section{DAFTAR PUSTAKA}

Berk, Laura E. 2006. Child Development. New York: Pearson Press, Inc.

Brown, H. Douglas. 1991. Breaking the Language Barrier. Yarmouth: Intercultural Press, Inc.

Cole, Michael., and Sheila R. Cole. 2001. The Development of Children. New York: Worth Publishers.

Cameron, Lynne. 2001. Teaching Language to Young Leraners. Cambridge: CUP

Goffman, Erving. 1990. The Presentation of Self in Everyday Life. Tersedia: http://en.wikipedia.org/wiki/Empiricist [29 Mei 2013]

Majid, Abd. Penguatan Budaya Lokal Dalam Pendidikan Global. Tersedia: http:// abdmajid.staf.upi.edu/2013/08/27/penguatan-budaya-lokal-dalampendidikan-global/ [Tersedia: 6 Maret 2014]

Phillips, Sarah. 1993. Young Learners. UK: Oxford University Press.

Pinker, Steven. 1996. Language Learnability and Language Development. US: University Press.

Pinter, Annamaria. 2006. Teaching Young Language Learners. UK: Oxford University Press.

Santoso, Iman. Pembelajaran Bahasa Asing di Indonesia: antara Globalisasi dan Hegemoni. 
http://www.academia.edu/5180839/Pembelajaran_Bahasa_Asing_

di_Indonesia_antara_Globalisasi_dan_Hegemoni [Tersedia: 5 Maret 2014]

Orr, Jannet K. 1999. Growing Up with English. Washington, DC 20547: Office of English Language Programs. United States Department of State.

http://en.wikipedia.org/wiki/Empiricist 